\title{
低水路沿いの樹木が複断面蛇行水路の 洪水流の挙動に及ぼす影響 \\ EFFECTS OF VEGETATION ALONG A LOW-WATER CHANNEL ON BEHAVIOR OF FLOOD FLOWS IN A MEANDERING COMPOUND CHANNEL
}

\author{
重枝 未玲 1 ・朝位 孝二 2 - 坂本 洋 3 ・西尾 崇 4 ・秋山 壽一郎 ${ }^{5} \cdot$ \\ 石原 仁 6 樋口 直樹 6 ・徳永 智宏 3 \\ Mirei SHIGE-EDA, Kouji ASAI, Hiroshi SAKAMOTO, Takashi NISHIO, Juichiro AKIYAMA, \\ Jin ISHIHARA, Naoki HIGUCHI and Tomohiro TOKUNAGA \\ 1正会員 博士(工) 九州工業大学助教授 工学部建設社会工学科(广804-8550 北九州市戸烟区仙水町1-1) \\ 2正会員 博士(工) 山口大学助教授 工学部社会建設工学科(广755-8611宇部市常盤台 2-16-1) \\ 3正会員 株式会社 建設技術研究所 九州支社河川部 (†810-0041 福岡市中央区大名 2-4-12 CTI 福岡ビル) \\ 4正会員 国土交通省九州地方整備局大分河川国道事務所所長 (广870-0820 大分市西大道 1-1-71) \\ 5 フェロー会員 Ph.D. 九州工業大学教授 工学部建設社会工学科(同上) \\ 6学生会員 九州工業大学大学院 工学研究科建設社会工学専攻(同上)
}

\begin{abstract}
The effects of low-water channel alignment and the position of vegetation on the behavior of flood flows in a compound open channel were investigated experimentally and numerically. The relative depth and position of vegetation were changed in experiments. The numerical model based on a finite-volume method on unstructured grid using flux-difference spitting technique was used in numerical simulations. Through the experiments and numerical simulations, it is found that the changes of flow pattern due to relationship between sinuosity and relative depth as well as the relation between a location of maximum velocity and vegetation in the channel were related to increasing of flow resistance and bank protection.
\end{abstract}

Key Words : vegetation, meandering compound channel, flood flow, experiments, numerical simulation

\section{1.はじめに}

河道内樹木は，自然景観や生態系などの環境面や 堤防や河岸の保護などの治水面で重要な役割を果た している，一方で，河道内樹木は河道の流下能力を 低減させ，治水面上問題を引き起こす場合がある. 幾つかの河川では出水時に河道内樹木が集中繁茂す る区間で計画高水位を上回った報告 ${ }^{1)}{ }^{2)}$ がなされて いる.

従来, 河道内樹木は治水安全度の確保が困難と なった場合に伐採管理が行われてきた。しかし，近 年では観測史上最大規模やそれに近い豪雨が頻発し ていることを踏まえると，今後，治水と環境の両機 能を考慮にいれた河道内樹木の適正な管理の重要性 が益々高まると考えられる。

河道内樹木の管理については，「河川における樹
木管理の手引き」 ${ }^{3)} に$ 取りまとめられている。この 中では，樹木伐採範囲は，洪水流下を阻害寸る樹木 を想定し，準2次元解析により洪水時の水位と安全 水位との関係などを踏まえた上で決定することが望 ましいとされている. つまり, 効果的な樹木管理を 行うためには, 洪水時に流下阻害となる河道内樹木 の判別が重要になる.

福岡 ${ }^{4), 5)}$ は, 洪水防備林を対象に, 洪水時の流 れや河床変動に及ぼす影響, 洪水防備林の伐採に伴 う低水路の護岸化が治水面に及ぼす影響について検 討し, 水害防備林が低水路内の流量を減少させるこ と, 伐採する樹木の位置によっては水衝部を移動さ せ, 水害防備林の倒伏や流出を引き起こす可能性が あること，などを示した．堤防や低水路などの河道 線形と河道内樹木の位置は, 水位上昇等の洪水流の 挙動に密接に関係しており, これらの関係を明確に することは，効果的な樹木管理を行う上で極めて重 


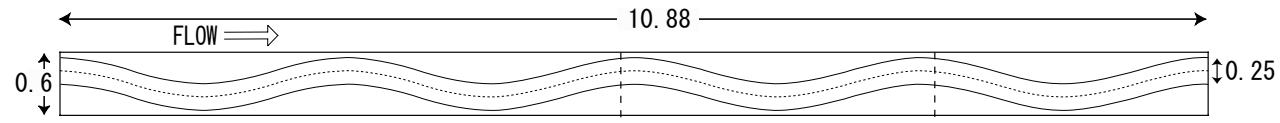

(a) Case 1-a,Case 2-a

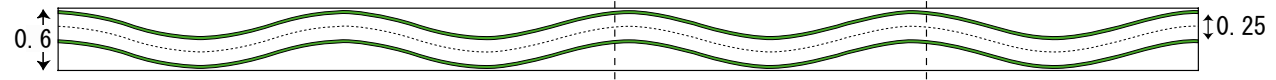

(b) Case 1-b,Case 2-b

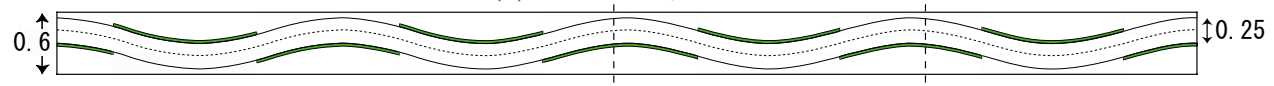

(c) Case 1-c

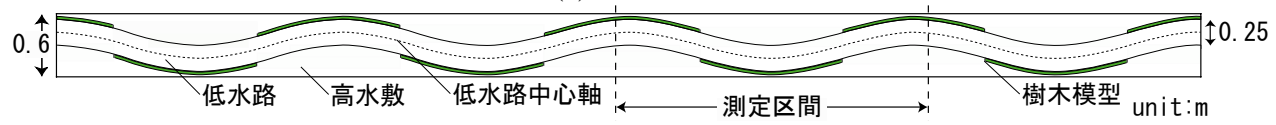

(d) Case 1-d

図-1 複断面直線水路と樹木繁茂位置

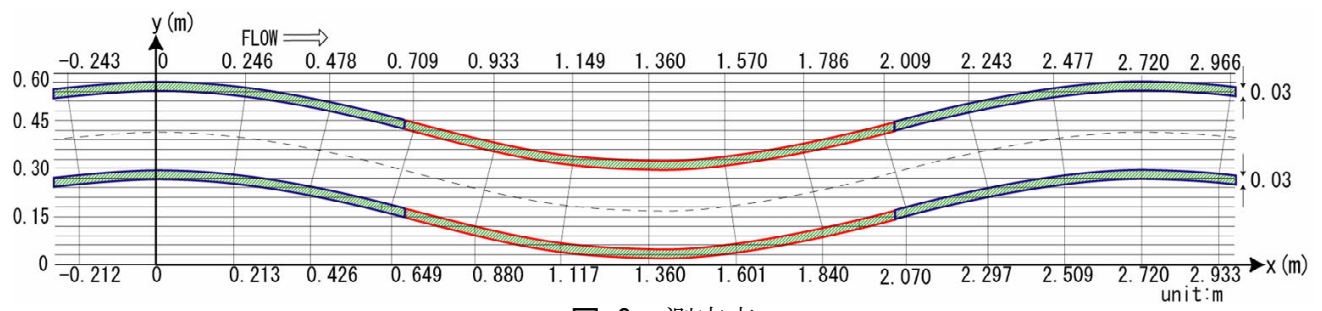

図-2 測定点

要である。

本研究は，河道内樹木の効率的かつ効果的な管理 方法の確立を目的としている。ここでは，複断面蛇 行水路の低水路形状と樹木繁茂位置が洪水流の挙動 に及ぼす影響について，実験および解析に基づき検 討した。

\section{2. 実験と解析の概要}

実験装置は, 可変勾配開水路(長さ $L=20.5 \mathrm{~m}$, 幅 $B=0.6 \mathrm{~m})$ である. 可変勾配開水路内には，図-1に示 す発泡スチロール製の蛇行低水路を設けた複断面直 線水路 (長さ $10.88 \mathrm{~m}$, 低水路幅 $0.25 \mathrm{~m}$, 高水敷幅 $0.35 \mathrm{~m}$ ，高水敷高さ $0.05 \mathrm{~m}$ )が設置されている. 高水 敷には粒径 $d=0.75 \mathrm{~mm}$ の珪砂を敷設し, 低水路より 粗度係数 $n$ を大きくした。高水敷と低水路の粗度係 数 $n$ は，それぞれ0.016と0.009である.

低水路線形はSine-generated curveに従って蛇行し ており，蛇行部は4波長設けた。その平面形状は， わが国の河川の平面形状特性の統計資料 ${ }^{6}$ を踏まえ, 蛇行度(低水路蛇行長/低水路蛇行波長)が 1.02 , 低水 路幅と水面幅との比が 0.42 , 低水路幅と蛇行帯幅と の比が 0.5 , 低水路幅と蛇行波長との比が 0.092 にな るように設定した。

流れは，相対水深(高水敷水深/低水路水深) と蛇行 度との関係 ${ }^{6)}$ から, 低水路線形が流れに影響を与 えず流れの直進性が大きくなる複断面蛇行流れ (Case 1) と低水路線形が流れに影響を与える複断面 蛇行流れ(Case 2) とした. 水理条件と水路床勾配は 表-1に示す通りである。
表-1 実験条件

\begin{tabular}{|c|c|c|c|c|}
\hline & 流量 $Q\left(\mathrm{~m}^{3} / \mathrm{s}\right)$ & 勾配I & 蛇行度S & 相対水深Dr \\
\hline Case 1-a & \multirow{4}{*}{0.0221} & \multirow{4}{*}{$1 / 1667$} & \multirow{6}{*}{1.02} & 0.49 \\
\hline Case 1-b & & & & 0.65 \\
\hline Case 1-c & & & & 0.59 \\
\hline Case 1-d & & & & 0.57 \\
\hline Case 2-a & \multirow{2}{*}{0.0095} & \multirow{2}{*}{$1 / 500$} & & 0.29 \\
\hline Case 2-b & & & & 0.35 \\
\hline
\end{tabular}

樹木繁茂状況は，図-1に示すように，繁茂してい ない場合(Case 1-a，2-a)，樹木群が低水路沿いの全 区間で繁茂した場合(Case 1-b，2-b)，低水路内岸部 に繁茂した場合(Case 1-c), 低水路外岸部に繁茂した 場合(Case 1-d)の4通りとした。このような低水路と 高水敷の境界に樹木群が繁茂する状況は，樹木群が 河道に沿って繁茂する場合に引堤などの河川改修を 行うことで生じる. 樹木群は透過係数 $K_{\mathrm{s}}=0.31(\mathrm{~m} / \mathrm{s})$ のプラスチック製の糸が絡み合った多孔体でモデル 化した．樹木群の幅は $0.03 \mathrm{~m}$ した.

いずれのCaseについても定常状態を確認した後, 測定を開始した。測定項目は水深 $h$ と $x, y$ 方向の流 速であり，それぞれ容量式波高計と2次元電磁流速 計を用い測定した。上流から3波長目を測定区間と した。測定点は低水路では低水路線形に沿って，高 水敷では水路線形に沿って設定されており，作業の 容易さから次のように求めた。 まず, 低水路の1波 長を低水路中心軸に沿って12分割し, 分割点での中 心軸の法線と, 法線と低水路境界との交点を始点と した $y$ 軸に沿った直線を描いた。次に，y軸方向につ いて水路を20分割する $x$ 軸に沿った線を描いた。互 いの線の交点を測定点とした。測定点は図-2に示す 通りである. なお, Case 2の流速測定については高 


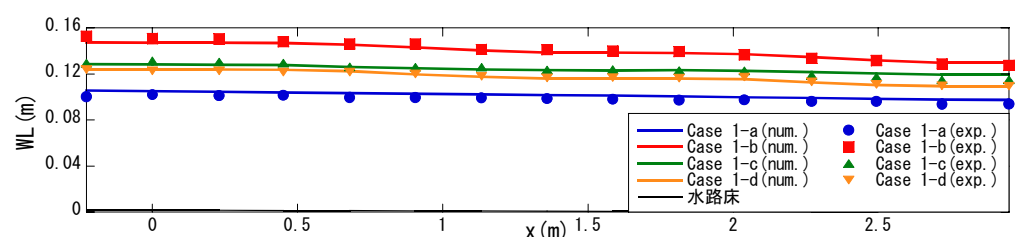

(a) Case 1

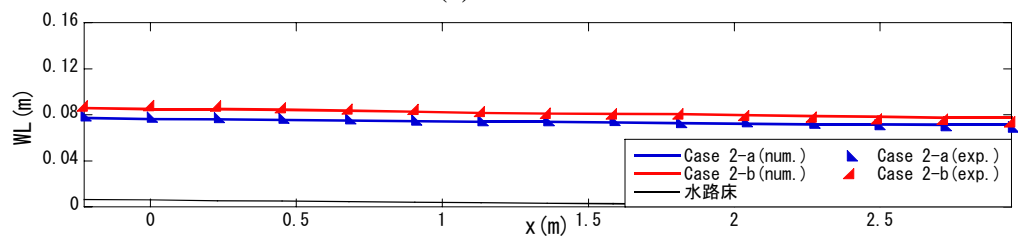

(b) Case 2

図-3 低水路中心軸の水位

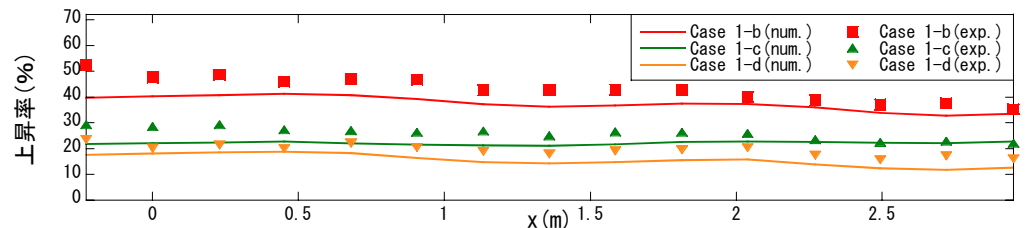

(a) Case 1

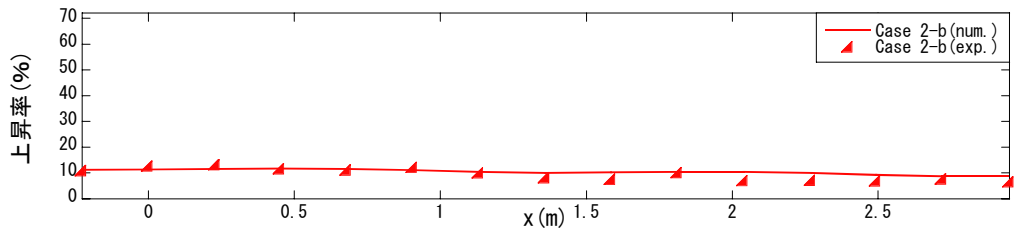

(b) Case 2

図-4 樹木繁茂状況による水位の上昇率

水敷の水深が浅いために，低水路のみで行っている. 流速測定では，各測定点で河床から鉛直方向に水深 の2割，3.5割及び8割の位置で計測し，1点法，2点 法により $x, y$ 方向の水深平均流速 $u, v$ を算定した. 両者には有意な差は生じなかったので, 以下では2 点法の結果を示している. 水深, 流速測定のサンプ リング間隔，サンプリング時間はそれぞれ 0.05 秒, 90秒である。

解析には，著者等が開発したSA-FUF-2DFモデル7) を用いた．SA-FUF-2DFモデルでは樹木群は $x$ 方向， $y$ 方向の運動方程式にそれぞれ $F_{\mathrm{x}}=C_{\mathrm{d}} \cdot \mathrm{a} / 2 \cdot$ $u h\left(u^{2}+v^{2}\right)^{0.5}, \quad F_{\mathrm{y}}=C_{\mathrm{d}} \cdot \mathrm{a} / 2 \cdot v h\left(u^{2}+v^{2}\right)^{0.5}$ で表される空間 平均された流体力項を付加することで取り扱われ $ろ^{7)}$. ここに, $a=$ 樹木群密度パラメーター $(=d \cdot N)$, $d=$ 樹木の投影幅, $N=$ 樹木密生度 $\left(\right.$ 本 $\left./ \mathrm{m}^{2}\right)$ および $C_{\mathrm{d}}=$ 抵 抗係数であり，各パラメーターは，樹木繁茂状況に 応じて設定される。また，透過係数 $K_{\mathrm{s}}$ はこれらの諸 量を用いると, $K_{\mathrm{s}}=1 /\left(a \cdot C_{\mathrm{d}} / 2 g\right)^{0.5}$ で表される。境界 条件として上流端には表-1の流量を, 下流端には水 位を与えた。

\section{3. 結果と考察}

以下では，実験および解析結果に基づき，複断面 蛇行水路で発生する流れ, 最大流速の発生位置, 樹
木繁茂位置が水位上昇や底面せん断応力に及ぼす影 響について検討する。

\section{（1）水位と水位上昇率}

図-3は低水路中心軸上の水位の実験值と解析結果 を, 図-4は樹木繁茂状況による水位上昇率を調べた ものである. 水位上昇率は次式で定義される。

上昇率 $(\%)=\frac{\text { 水位 }(\text { Case1-b, }, \mathrm{d} \text {, or 2-b) }- \text { 水位 }(\text { Case1-a or 2-a })}{\text { 水位 }(\text { Case1-a or } 2-a)} \times 100$

解析結果と実験值とを比較すると, SA-FUF-2DFモ デルが平面2次元モデルであり低水路で発生する2次 流を考慮できないため, 若干の誤差は生じている.

しかし，いずれのCaseについても水位および水位上 昇率のいずれも解析結果は実験值を概ね再現してい ることがわかる。

図-3に着目すると，Case 1については，(1) Case 1-b, $\mathrm{c}, \mathrm{d}, \mathrm{a}$ の順に水位が全体的に下がること, また, 水面勾配が緩くなること，(2) 樹木繁茂面積が同じ にもかかわらず, Case 1-bからcへの水位低下に比べ, Case 1-bからdへの水位低下の割合が大きいこと, など がわかる。また，Case 2については，(1) Case 2-bに 比べ, Case 2-aの水位は若干低下すること，(2) 水面 勾配にはさほど違いがないこと，などがわかる。

図-4に着目すると，水位上昇率は全区間で概ね一 定で，樹木が低水路沿いに繁茂するCase 1-b，樹木 


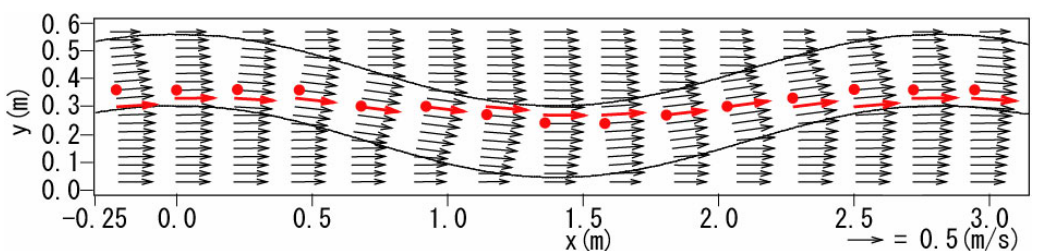

(a) Case $1-\mathrm{a}$

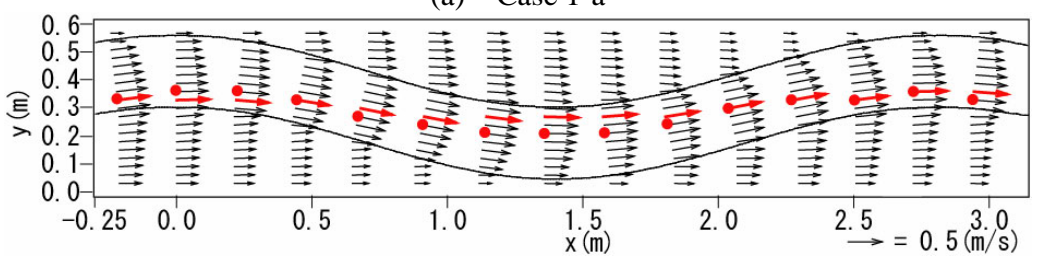

(b) Case 2-a

図-5 Case 1-a と2-aの流速ベクトルの比較

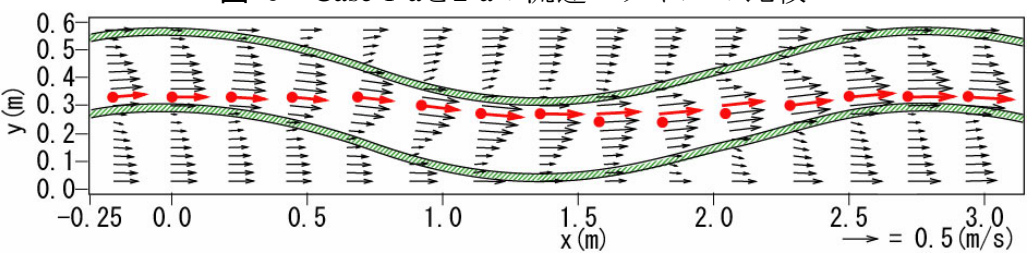

(a) Case 1-b

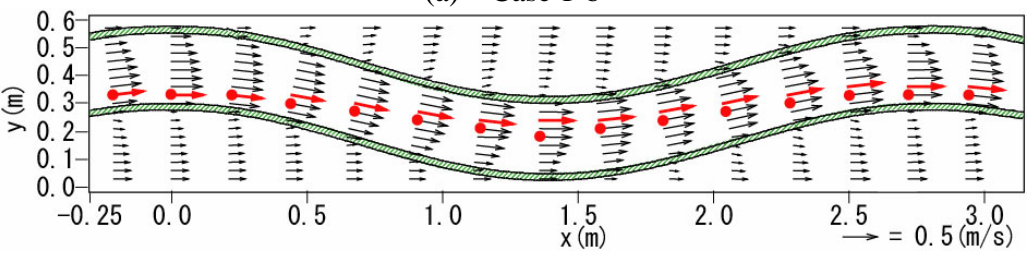

(b) Case 2-b

図-6 Case 1-bと2-bの流速ベクトルの比較

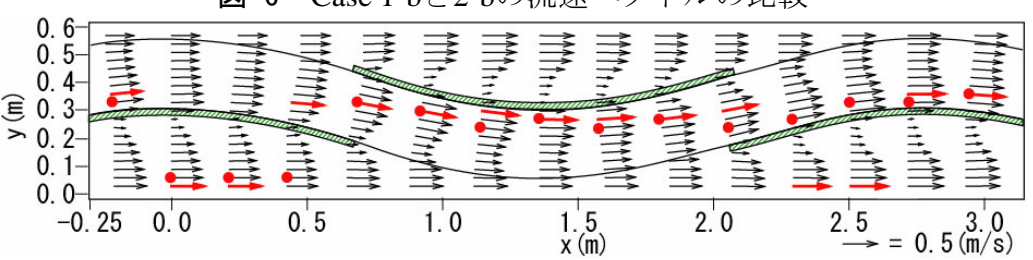

(a) Case 1-c

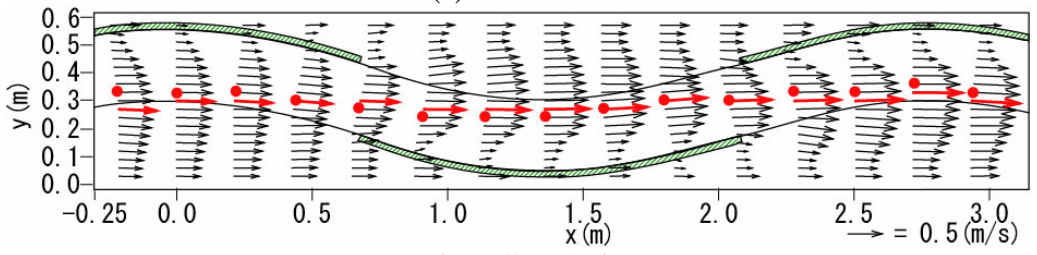

(b) Case 1-d

図-7Ｃase 1-c と1-dの流速ベクトルの比較

が低水路内岸側に繁茂するCase 1-c，低水路外岸側 に繁茂するCase 1-d，低水路沿いに繁茂するCase 2-bの 順番に上昇率が大きくなることがわかる. Case 1-b と Case 2-b，Case 1-cとdは，それぞれ樹木繁茂面積は 等しい。従って, 水位上昇率の違いは, Case 1-bと Case 2-bについては水路内で生じる流況により, Case 1-cとdについては樹木繁茂位置により生じたと 考えられる.

\section{（2）流速ベクトルと最大流速の発生位置による水位 上昇率の変化}

以下では，流速ベクトルと最大流速の発生位置お よび樹木繁茂位置に着目し，水位上昇率の違いにつ
いて検討する。

まず，蛇行複断面水路で生じる流れが水位上昇率 に及ぼす影響について検討する。図-5は，樹木が繁 茂していない場合のCase 1-aとCase 2-aについて流速 ベクトルの解析結果を示したものである。なお，実 験結果も同様な傾向を示しており，図中の赤のベク トルは解析により, シンボルは実験より求めた最大 流速の発生位置である。これより，(1) 低水路の影 響が小さい条件のCase 1-aでは，低水路形状の影響 を若干受けるものの, Case 2-aよりも直進性が強く 全体的には水路形状に沿った流れが生じていること, (2) 一方, Case 2-aでは低水路で低水路線形に沿った 流れが生じていること，(3) また，Case 1-aについ 


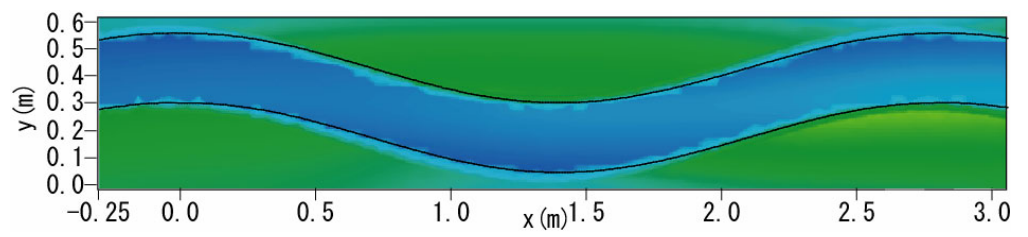

(a) Case 1-a

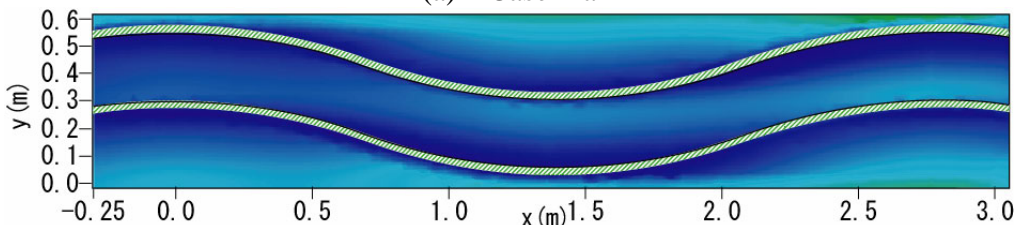

(b) Case 1-b

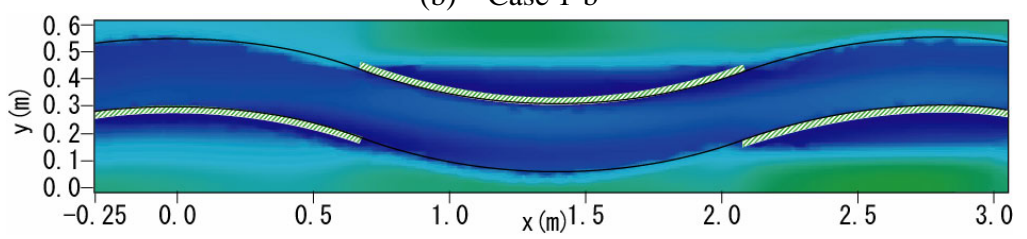

(c) Case 1-c

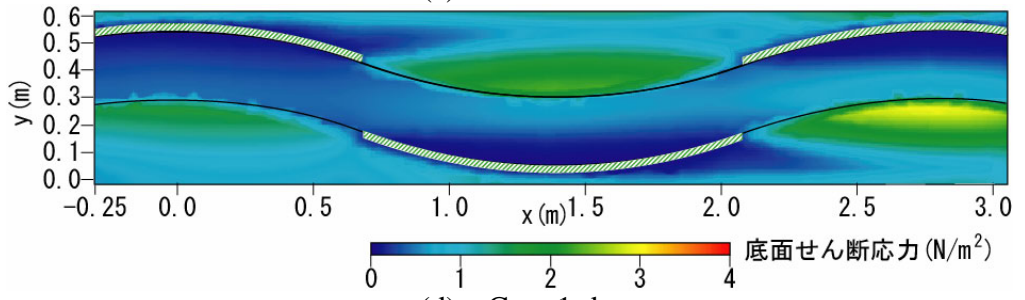

(d) Case 1-d

図-8 底面せん断応力の比較

ては最大流速の発生位置は直線的なのに対して, Case 2-aでは低水路線形の影響を受け，水路中央か ら内岸よりに最大流速が生じていること，などがわ かる。

図-6は，樹木が低水路沿いに繁茂している場合の Case 1-bとCase 2-bについて，流速ベクトルの解析結 果を示したものである。図-5と比較すると，低水路 での流れは (1) Case 2-bについては流速ベクトルお よび最大流速発生位置のいずれもCase 2-a と大きな 違いはないこと, (2) Case 1-bについては樹木により 低水路沿いの流れが生じ, Case 1-a とは異なった流 れが生じていること，などがわかる。

以上から，蛇行度と相対水深との関係 ${ }^{6}$ により複 断面蛇行水路内で生じる流れが，Case 1-bとCase 2-b の水位上昇率に大きな違いを生じさせたと考えられ る.つまり，複断面水路では蛇行度と相対水深との 関係 ${ }^{6)}$ が，低水路線形の影響を受ける領域に位置す る場合には，主な流れは低水路に沿って生じるため 樹木の境界で働くせん断応力が水位上昇を引き起こ す主な要因と考えられる。一方，低水路線形の影響 を受けない領域に位置する場合には，樹木境界での せん断応力に加え, 流れの直進性が増すことで生じ る樹木からの抗力が水位上昇を引き起こす主な要因 と考えられる. このような流れに作用する抵抗の違 いが水位上昇率の違いを生じさせたと考えられる。

次に，樹木繁茂位置が水位上昇率に及ぼす影響に ついて検討する，先述したように，樹木が水位上昇
に及ぼす影響は，低水路線形の影響を受けない複断 面的流れの場合に大きくなる。従って，ここでは Case 1についてのみ樹木を部分的に配置している.

図-7は，樹木が内岸側に繁茂する場合のCase 1-c と外岸側に繁茂するCase 1-dについて，流速べクトル の解析結果を示したものである.内岸側はCase 1-aの 最大流速が生じる位置に近い樹木であり，外岸側は その反対の樹木である。これより，(1) Case 1-cでは 内岸側の樹木により流れが 2 分され，水路側壁付近 で大きな流速が生じていること，(2) Case 1-dでは樹 木周辺の流速は減速しているものの, 最大流速発生 位置などはCase 1-a と大きな違いはないこと, など がわかる。

以上から, Case 1-cとCase 1-dの水位上昇率の違い は，最大流速の発生位置と樹木の繁茂位置との相対 的な関係により生じたと考えられる.つまり, 最大 流速が発生する位置に樹木繁茂位置がある場合に, 流れは樹木からより大きな抗力受けるためCase 1-c の水位上昇率が大きくなったと考えられる.

このように, 樹木繁茂位置, 蛇行度と相対水深と の関係により変化する蛇行水路内の流れと最大流速 の発生位置が，水位上昇に及ぼす影響がわかった。 従って，このような領域にある樹木を伐採すれば， 効果的に河道の流下能力を向上できると考えられる.

\section{（3）樹木繁茂位置による底面せん断応力の変化}

低水路沿いの樹木の伐採は，流下能力を向上させ 
る。一方で，区間伐採を行う場合には伐採区間の選 定によっては低水路と高水敷の境界付近の河床せん 断応力や堤防と樹木の間の流速を増加させる可能性 がある。これは, 高水敷の崩壊ひいては護岸崩壊や 堤防崩壊につながる恐れがあるため，この点につい ても注意が必要となる ${ }^{4)}$.

図-8 は, Case 1-a $-\mathrm{d}$ につて Manningの式 $\left(\rho g n^{2}\left(u^{2}+v^{2}\right) / h^{1 / 3}\right)$ を用いて求めた底面せん断応力分布 図である。ここに永の密度である. なお, 実験 值について同様な傾向が認められたので，ここでは 解析結果のみを示している. 先述したように, 解析 に用いたSA-FUF-2DFモデルは低水路で発生する2次 流を考慮できないため底面せん断応力には誤差があ る. しかし, Case 1-a，2-aの水位について解析結果 と実験值との間に大きな違いが生じていないことか ら, その分布については概初再現していると考えら れる．図-8より，(1) 樹木が低水路沿いに繁茂する Case 1-bについては, Case 1-aに比べ, 低水路沿いの 底面せん断応力が全体的に小さいこと，(2) 一方で, 樹木と水路側壁間の距離が小さな箇所では流れが加 速されるため, 大きな底面せん断力が働いているこ と，などがわかる。また， Case 1-cについては，(1) 樹木により流れが2分されるために, 高水敷に水が乗 り上がり，水路幅との関係もあるが，水路側壁付近で 樹木がないCase 1-a と同程度の底面せん断応力が生じ ていることがわかる，一方，Case 1-dについては，(1) 低水路内岸でCase 1-a よりも大きな底面せん断応力 が生じていること，などがわかる.

このように，樹木の繁茂位置によっては，低水路 内岸や堤防付近で大きな底面せん断応力を引き起こ 寸場合があり, 低水路内岸側や堤防付近で洗掘を生 じさせる危険性がある. 従って, 樹木伐採を行うに 当っては, 流下能力の向上だけでなく, 樹木繁茂位 置による底面せん断応力の変化についても検討する 必要があると考えられる，ただし，これらの結果は， 堤防線形と低水路線形および樹木配置位置が相互に 関係していると考えられることから，様々な組み合 わせについて検討していく必要がある.

以上のように, 複断面での流況, 最大流速の発生 位置および河道内樹木の位置は, 流れの抵抗を増大 させることや河岸や堤防保護に密接に関係している ことが確認された。

\section{4.おわりに}

本研究では, 河道内樹木の効率的かつ効果的な管
理方法の確立を目的に, 直線複断面河道の低水路形 状と樹木繁茂位置が洪水流の挙動に及ぼす影響につ いて, 実験および解析に基づく検討を行った。 その 結果, 以下のことが確認された。

(1) 蛇行度と相対水深との関係 ${ }^{6}$ により生じる流況 の変化が, 流れの抵抗の増大や河岸や堤防保護 に密接に関係していること

(2) 最大流速の発生位置および河道内樹木の位置の 相対的な関係が, 流れの抵抗の増大や河岸や堤 防保護に密接に関係していること

今後は, 数值シミュレーションや実験を通じて, 様々な堤防線形や低水路蛇行形状について検討して いきたいと考えている.

謝辞 : 本研究は, 河川懇談会の活動の一環として, 国土交通省大分河川国道事務所と共同で研究を行っ たものである，本研究を実施するに当たり，大分河 川国道事務所の関係各位にはデータ提供などの多大 な協力を得た. また, 九州工業大学工学部生 中江 邦昭君には実験を行うにあたり協力を得た。ここに 記して感謝の意を表します。

\section{参考文献}

1) 桑原正人, 藤堂正樹, 小笠原豊, 石尾年光, 石井克尚, 犬丸潤, 中村敬司 : 加古川の河道内樹木の生長特性を 考慮した管理方法, 河川技術論文集, 第12巻, pp.461464, 2006.

2) 重枝未玲, 朝位孝二, 坂本洋, 長太茂樹, 秋山壽一郎, 樋口直樹, 重岡広美, 徳永智宏: 樹木群を考慮した平 面2次元モデルによる乙津川の洪水流解析, 水工学論文 集, 第50巻, pp.1171-1176, 2006.

3) 財団法人リバーフロント整備センター(編)：河川にお ける樹木管理の手引き, 山海堂, 1999.

4) 福岡捷二, 五十嵐崇博, 高橋宏尚 : 江の川水防林の特 性と治水効果, 水工学論文集, 第39巻, pp.501-506, 1995.

5) 福岡捷二, 川岡秀和, 平林由希子 : 水害防備林と低水 路線形が洪水流に与える影響, 水工学論文集, 第 42 巻, pp.967-972, 1998.

6) 岡田将治, 福岡捷二, 貞宗早織: 複断面蛇行河道の平 面形状特性と蛇行度, 相対水深を用いた洪水流の領域 区分，水工学論文集，第46巻，pp.761-766， 2002.

7) 重枝未玲, 秋山壽一郎：数值シミュレーションに基づ く堤防に沿った樹林帯の治水機能の検討, 土木学会論 文集，No.740/II-64，pp.19-30， 2003.

(2006. 9. 30受付) 